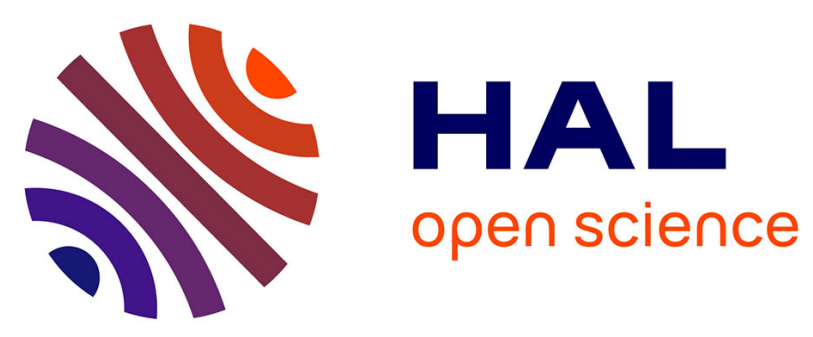

\title{
Imaging the megathrust in subduction zones: lessons from Greece, Ecuador and the Lesser Antilles
}

\author{
Mireille Laigle, Hans Agurto-Detzel, Anne Bécel, Milton Boucard, Caroline \\ Chalumeau, Philippe Charvis, Jean-Xavier Dessa, Audrey Galve, Maria-José \\ Hernandez, Sara Hussni, et al.
}

\section{To cite this version:}

Mireille Laigle, Hans Agurto-Detzel, Anne Bécel, Milton Boucard, Caroline Chalumeau, et al.. Imaging the megathrust in subduction zones: lessons from Greece, Ecuador and the Lesser Antilles. European Geophysical Union General Assembly, May 2020, Vienne, Austria. 10.5194/egusphere-egu202014636 . hal-03360728

\section{HAL Id: hal-03360728 \\ https://hal.science/hal-03360728}

Submitted on 11 Oct 2021

HAL is a multi-disciplinary open access archive for the deposit and dissemination of scientific research documents, whether they are published or not. The documents may come from teaching and research institutions in France or abroad, or from public or private research centers.
L'archive ouverte pluridisciplinaire $\mathbf{H A L}$, est destinée au dépôt et à la diffusion de documents scientifiques de niveau recherche, publiés ou non, émanant des établissements d'enseignement et de recherche français ou étrangers, des laboratoires publics ou privés. 
EGU2020-14636

https://doi.org/10.5194/egusphere-egu2020-14636

EGU General Assembly 2020

(c) Author(s) 2021. This work is distributed under

the Creative Commons Attribution 4.0 License.

\section{Imaging the megathrust in subduction zones: lessons from Greece, Ecuador and the Lesser Antilles}

Mireille Laigle ${ }^{1}$, Hans Agurto-Detzel ${ }^{1}$, Anne Bécel ${ }^{2}$, Milton Boucard ${ }^{3}$, Caroline Chalumeau ${ }^{1}$, Philippe Charvis ${ }^{1}$, Jean-Xavier Dessa ${ }^{1}$, Audrey Galve ${ }^{1}$, Maria-José Hernandez ${ }^{1,9}$, Sara Hussni ${ }^{1}$, Frauke Klingelhoefer ${ }^{4}$, Heidrun Kopp ${ }^{5}$, Muriel Laurencin ${ }^{6,10}$, Jean-Frédéric Lebrun ${ }^{3}$, Boris Marcaillou, François Michaud ${ }^{1}$, Michele Paulatto ${ }^{7}$, Alessandra Ribodetti ${ }^{1}$, Maria Sachpazi ${ }^{8}$, and Laure Schenini ${ }^{1}$ 'Université Côte d'Azur, Observatoire Côte d'Azur, CNRS, IRD, Geoazur, Valbonne Sophia Antipolos, France (laigle@geoazur.unice.fr)

${ }^{2}$ Lamont-Doherty Earth Observatory, Columbia University, Palisades, USA

${ }^{3}$ Géosciences Montpellier, UMR5243, Université des Antilles, CNRS, Université de Montpellier, Campus de Fouillole, Pointeà-Pitre, Guadeloupe (FWI)

${ }^{4}$ IFREMER, Laboratoire Aléas géologiques et Dynamique sédimentaire (PDG-REM-GM-LAD), Plouzané, France

${ }^{5}$ GEOMAR, Dynamics of the Ocean Floor, Marine Geodynamics, Kiel, Germany

${ }^{6}$ Laboratoire Géosciences Océan, CNRS-UBO-UBS, Université Bretagne Pays de Loire, Plouzané, France

${ }^{7}$ Imperial College London, Earth Science and Engineering, London, United Kingdom

${ }^{8}$ Institute of Geodynamics, National Observatory of Athens, Athens, Greece

${ }^{9}$ Departamento de Geología, Escuela Politécnica Nacional, Ladrón de Guevara E11 - 253, Quito Ecuador

${ }^{10}$ Earth Observatory of Singapore, Nanyang Technological University, Singapore

Understanding the physical parameters and processes that control the seismogenic behavior of subduction zones megathrust faults remains one of the outstanding challenges in Earth Sciences.

Here we present important results from several large seismic experiments aimed at addressing this question. These experiments focused on the three subduction zones off Greece, the Lesser Antilles islands, and Ecuador, with different convergence rates and seismic activities. Surveys included multibeam bathymetry, multichannel reflection seismic (MCS) and wide-angle seismic (WAS) acquisitions over the forearc domain, as well as teleseismic receiver-functions and local earthquakes monitoring with temporary deployments of seismological networks.

Our results demonstrate the needs of both dense and extensive geophysical investigations.

In the central Lesser Antilles subduction zone, the interplate has been imaged down to the backstop at $12-15 \mathrm{~km}$ depth over the 350-km-long Antigua to Martinique islands segment. The outer forearc crust is strongly faulted in response to the two subducting Tiburon and Barracuda ridges (SISMANTILLES1-and-2 surveys). Two WAS profiles constrained the deeper geometry of the interplate down to the forearc Moho located at $28 \mathrm{~km}$ depth (TRAIL survey). The OBS networks deployed over several months (OBSANTILLES and OBSISMER surveys) revealed mantle wedge supraslab earthquakes and M4-5 possible repeaters with flat-trust mechanisms. The joint active- 
source/local earthquake seismic tomography let us to unveil the $\mathrm{Vp}$ and $\mathrm{Vp} / \mathrm{Vs}$ heterogeneity along the slab surface and derive unprecedented constraints on multi-stage fluid release from subducting slow-spread oceanic lithosphere. Farther northwest, where the convergence obliquity strongly increases, we constrained the geometry of the interplate down to the forearc Moho at 25 $\mathrm{km}$ depth. Strain partitioning localizes on inherited major structures within the forearc domain, like the left-lateral partitioning system of the Anegada Passage and the 850-km-long Bunce fault, located along the backstop (ANTITHESIS survey).

On the southwestern Hellenic subduction zone, MCS and WAS acquisitions highlight the existence of an outer forearc crust beneath the forearc Matapan Trough, but its highly complex structure prevented us to image the interplate (ULYSSE survey). Acquisition by the R/V Marcus Langseth with its 8-km-long streamer finally made it possible (SISMED survey). Dense receiver-function acquisition on a 300-km-long mobile seismic network constrained the 3D geometry of the slab top underneath central Greece. This imaging revealed that the subducting oceanic crust and backstop updip limit are segmented by 9 trench-normal subvertical faults, seismically active at intermediate depths and possibly of inherited origin (THALES WAS RIGHT survey).

South of the 1906 M8.8 Ecuador-Columbia rupture area, the April 2016 Mw7.8 Pedernales subduction earthquake and its ensuing postseismic phase revealed a combination of seismic/aseismic slip behavior. Fluid-enriched parts of the megathrust fault and structural margin segmentation are hypothesized to play a major role in controlling slip behavior but direct observations are still lacking. Previous MCS acquisitions revealed very locally a fluid-rich subduction channel along with severe damage effect of the forearc margin due to seamounts subduction (SISTEUR survey). Forthcoming 3D seismic acquisition along this segment will examine the impact of the along-strike and along-dip variations of the physical properties and fluid content on the slip mode (HIPER survey). 